\title{
PRELIMINARY RESULTS OF ROCK- AND PALAEOMAGNETIC FIELD WORK IN PEARY LAND, NORTH GREENLAND
}

\author{
Niels Abrahamsen and Christian Marcussen
}

This paper reports on the palaeomagnetic field work carried out in the Peary Land region in 1979 (fig. 60) and presents some preliminary results of the laboratory investigations.

Previous work relating to the geomagnetic field in North Greenland is very limited, and no palaeomagnetic and rock-magnetic data from Peary Land have hitherto been published.

\section{Field work and sampling techniques}

The general purpose of the field work was to obtain as varied and extensive a collection as possible of orientated rock samples, from which various geomagnetic, palaeomagnetic, rock-magnetic, stratigraphical, and plate tectonic information could be derived.

The planning of the 1979 palaeomagnetic field work was based on general geological knowledge of Peary Land (Dawes 1973, 1976), and on preliminary measurements of the NRM (natural remanent magnetization) and the magnetic susceptibility of some 50 unorientated hand samples collected earlier by Dawes \& Soper (1973), Jepsen (1971), Christie \& Peel (1977), and Hurst \& Peel (1979).

The Precambrian basement in Wulff Land $\left(\sim 46^{\circ} \mathrm{W}\right)$ and the late Palaeozoic-Tertiary Kap Washington Group (fig. 60) were not sampled this summer because of difficulties with logistics and access, although, from a magnetic point of view they would have been very interesting.

In the field, cores (diameter $2.5 \mathrm{~cm}$, length 5 to $10 \mathrm{~cm}$ ) from volcanic and sedimentary rocks were obtained with a portable drill with water cooled diamond drill bits. However, lack of water or strong, cold winds sometimes made hand sampling more attractive. During the active field season (20th of June to 16 th of August) the temperature was generally between $+1^{\circ}$ and $+10^{\circ} \mathrm{C}$, so foreseen problems with freezing of the cooling water were not encountered.

All field cores (about 630) and most of the 285 hand samples were orientated by means of a sun compass. In the case of weakly magnetized rocks (i.e. sediments), a magnetic compass was used as a check.

Postglacial unconsolidated lake sediments were collected from two small lakes using a $60 \mathrm{~mm}$ Livingston type corer operating from a floating platform. The lakes were Klaresø south of Jørgen Brønlund Fjord (28 tubes with 0.5 to $0.8 \mathrm{~m}$ gyttja) and the water lake at Station Nord (fig. 60) (6 tubes with 0.3 to $0.6 \mathrm{~m}$ of postglacial sediment). Sampling from Fastelavnssø, north of Jørgen Brønlund Fjord (fig. 60), was unsuccessful as the flat part of the lake bottom was too deep (>7 m) for the equipment.

Two sections in a $10 \mathrm{~m}$, postglacial, marine silt sequence (about 7500 B.P.) on the south side of Jørgen Brønlund Fjord were also sampled; the results of these investigations are reported separately (Abrahamsen, this report). 


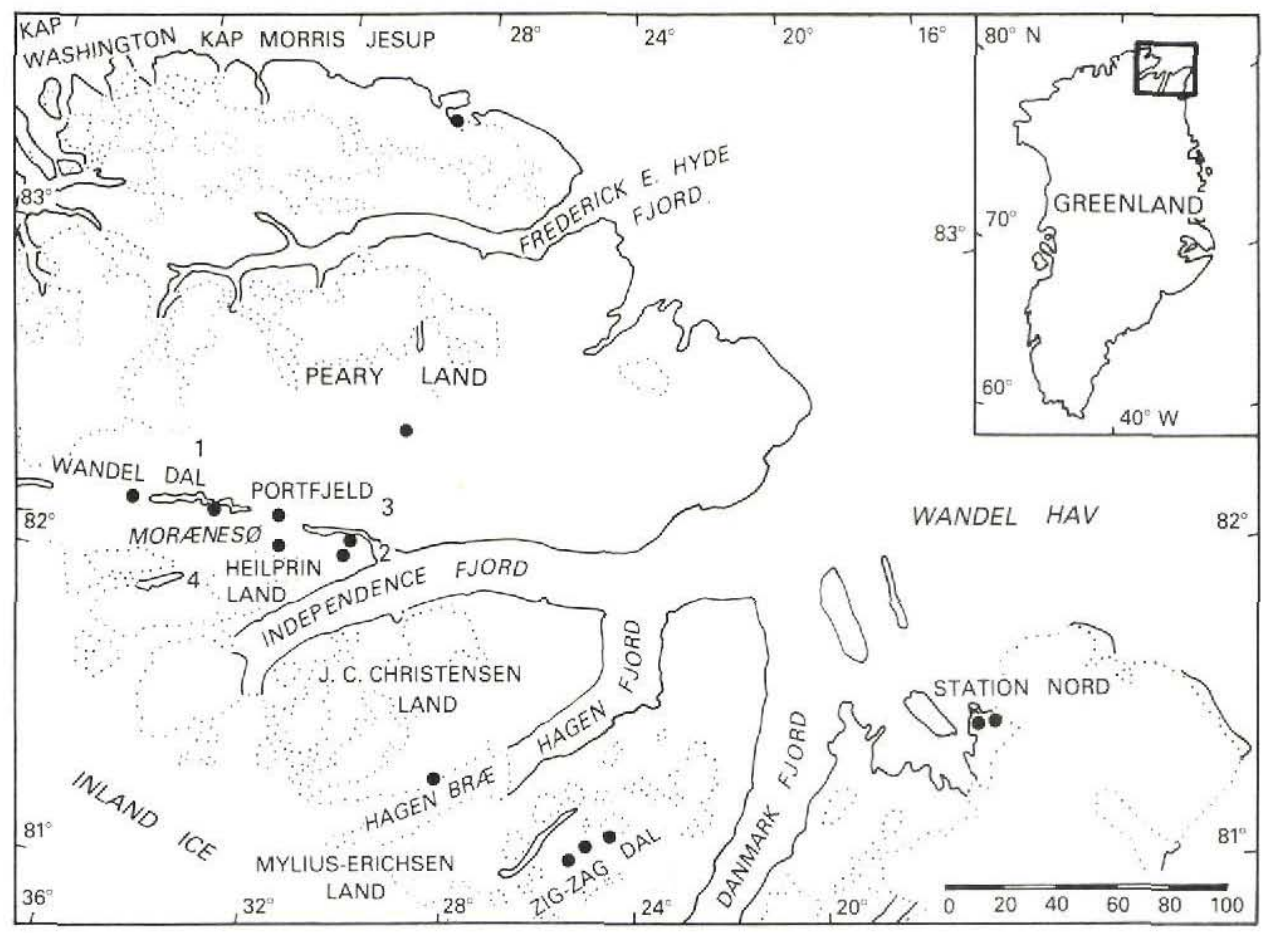

Fig. 60. Map of Peary Land, NE Greenland. Broken lines indicate ice-covered areas. Palaeomagnetic sampling areas are shown by dots (cf. Table 13). Localities: 1: Øvre and Nedre Midsommersø, 2: Jørgen Brønlund Fjord, 3: Fastelavnssø, 4: Itukussuk Dal.

Most of the rock- and palaeomagnetic information will be derived from laboratory investigations of the remanent magnetization, which are still in progress. Therefore, only preliminary results are reported here.

\section{Kap Washington volcanics}

In the Arctic Basin about $100 \mathrm{~km} \mathrm{NE}$ of Kap Morris Jesup (fig. 60) an extensive area, of the order of $100 \mathrm{~km} \times 100 \mathrm{~km}$, of the Morris Jesup Rise produces a pronounced regional aeromagnetic anomaly (Vogt et al., 1978). It has been suggested that this anomaly might be caused by rocks equivalent to the Kap Washington volcanics, exposed over an area of about $10 \mathrm{~km} \times 100 \mathrm{~km}$ on the north coast west of Kap Morris Jesup (Dawes, 1973, 1976; Larsen et al., 1978).

Magnetic measurements on samples from the volcanics of the Kap Washington Group (Table 12) show that 5 out of 13 samples are fairly magnetic with susceptibilities between 1 and $4 \times 10^{-3} \mathrm{G} / \mathrm{Oe}$, while the $\mathrm{Q}$ ratio (NRM/susc.) is less than 0.4. Positive aeromagnetic anomalies between $10^{2}$ and $10^{3}$ gammas may therefore be expected to be associated with the Kap Washington volcanics. 
Table 12. Rock-magnetic information from the Kap Washington Group and Precambrian crystalline basement rocks

\begin{tabular}{|c|c|c|c|c|c|c|c|}
\hline \multicolumn{2}{|c|}{ Formation } & GGU no. & $\begin{array}{l}\text { Collected } \\
\text { by }\end{array}$ & $\begin{array}{c}\text { NRM } \\
10^{-6} \mathrm{emu} / \mathrm{co}\end{array}$ & $\begin{array}{l}\text { susc. } \\
10^{-6} \mathrm{G} / \mathrm{Oe}\end{array}$ & $\mathrm{Q}=\frac{\mathrm{NRM}}{\mathrm{SUSC}}$ & Rock type \\
\hline Kap & ashington $\mathrm{Gp}$. & 53443 & P.R.D. \& N.J.S. & 76.29 & 1023.0 & 0.07 & mylonitized rhyolite \\
\hline- & - & 53444 & - - & 2.33 & 18.5 & 0.13 & rhyolitic tuff \\
\hline- & - & 53446 & $-\quad-$ & 1.55 & 28.7 & 0.05 & porphyritic rhyolite \\
\hline - & - & 53447 & $-\quad-$ & 0.53 & 11.7 & 0.05 & vesicular rhyolite \\
\hline - & - & 53449 & $-\quad-$ & 358.00 & 155.5 & 2.30 & zeolitic basalt \\
\hline- & - & 53450 & - & 19.59 & 196.3 & 0.10 & ignimbrite \\
\hline- & - & 53451 & $-\quad-$ & 89.45 & 1246.0 & 0.07 & mylonitized ignimbrite \\
\hline - & - & 53453 & $-\quad-$ & 29.20 & 576.0 & 0.05 & rhyolitic flow breccia \\
\hline - & - & 53454 & $-\quad-$ & 522.00 & 1289.0 & 0.41 & metagabbro \\
\hline - & - & 53455 & $-\quad-$ & 13.13 & 122.5 & 0.10 & mylonitized basalt \\
\hline . & - & 53466 & $-\quad-$ & 5.79 & 9.4 & 0.62 & felsite \\
\hline - & - & 53467 & $-\quad-$ & 552.00 & 1863.0 & 0.30 & mylonitized porphyritic rhyolite \\
\hline- & - & 53471 & $-\quad-$ & 625.00 & 4156.0 & 0.15 & porphyritic basalt \\
\hline Bas & hent, Wulff Ld. & 270513 & J.S.P. & 0.41 & 0.5 & 0.31 & red biotite granite \\
\hline- & - & 270514 & - & 106.03 & 2100.0 & 0.03 & $\begin{array}{l}\text { dark amphibolie gneiss } \\
\text { with sulphides }\end{array}$ \\
\hline- & - & 270515 & - & 37.69 & 108.0 & 0.19 & granitic biotite gneiss \\
\hline- & - & 270516 & - & 0.53 & 32.3 & 0.01 & dark greenish \\
\hline- & - & 270517 & - & 0.46 & $9.3^{\prime}$ & 0.02 & $\begin{array}{l}\text { dark fine-grained } \\
\text { biotite gneiss }\end{array}$ \\
\hline- & - & 270518 & - & 2.26 & 25.0 & 0.04 & black amphibolite \\
\hline
\end{tabular}

P.R.D. = P.R. Dawes; N.J.S. = N.J. Soper; J.S.P. = J.S. Peel.

The geological setting of the volcanics suggests a post-Lower Palaeozoic age (Dawes, 1973), and based on isotopic evidence (Larsen et al., 1978) a late Cretaceous age has been presumed. However, bryozoans, which were found during the summer, in interbedded fossiliferous limestones, suggest a Permian age for these rocks (Soper et al., this report).

\section{Zig-Zag Dal Basalt Formation}

\section{Geology}

The Zig-Zag Dal Basalt Formation is well developed in central Mylius-Erichsen Land and in the eastern part of J. C. Christensen Land (fig. 60) (Jepsen \& Kalsbeek, 1979; Jepsen et al., this report). The basalt covers an area of about $10000 \mathrm{~km}^{2}$, and it varies in thickness from $100 \mathrm{~m}$ to $1350 \mathrm{~m}$ (in Zig-Zag Dal). The basalt is divided into three units (Jepsen et al., this report): Basal unit (subaqueous), Aphyric unit, and Porphyritic unit (in ascending order). Some prominent flows can be traced from section to section, e.g. flow no. 51, flow no. 64, and flow no. 68 (fig. 61). The volume of flow no. 51 is estimated at $600 \mathrm{~km}^{3}$.

The basalt has yet to be successfully dated. However, granophyric intrusives, related to the basic Midsommersø dolerites (see below), have given ages of c. $1250 \mathrm{~m}$.y. (Rb-Sr), and it has been suggested that the basalt is genetically related to the dolerites (Jepsen \& Kalsbeek, 1979). The Zig-Zag Dal Basalt Formation overlies conformably the Proterozoic Independence Fjord Group, Fiil Fjord Member (Collinson, this report), and it is overlain uncon- 
Table 13. List of palaeomagnetic samples, North Greenland, 1979

\begin{tabular}{|c|c|c|c|c|c|c|c|}
\hline \multirow[t]{2}{*}{ Formation/rock type } & \multirow[t]{2}{*}{ Locality } & \multirow{2}{*}{$\begin{array}{r}\text { No. of } \\
\text { sites }\end{array}$} & \multirow{2}{*}{$\begin{array}{l}\text { No. of } \\
\text { profiles }\end{array}$} & \multicolumn{3}{|c|}{ No. of orientated } & \multirow[t]{2}{*}{ Total } \\
\hline & & & & samples & cores & tubes & \\
\hline Postglacial, marine sed. & S of Jørgen Brønlund Fjord & 2 & 2 & & $150 *$ & & 150 \\
\hline $\begin{array}{l}\text { Postglacial, limnic } \\
\text { (lake-sediments) }\end{array}$ & Klares $ø, S$ of J. Brønlund $\mathrm{Fj}$. & 1 & 28 & & $50 \star$ & 28 & 50 \\
\hline $\begin{array}{l}\text { Postglacial, limnic } \\
\text { (lake-sediments) }\end{array}$ & $\begin{array}{l}\text { Vands } \varnothing, 2 \mathrm{~km} \text { ESE of } \\
\text { Station Nord }\end{array}$ & 1 & 6 & & & 6 & \\
\hline Post-Palaeozoic dyke ${ }^{\dagger}$ & S of Slusen, Wandel Dal & 1 & & & 12 & & 12 \\
\hline Permo-Carboniferous Is. & $5 \mathrm{~km} E$ of Station Nord & 3 & & 10 & & & 10 \\
\hline Silurian flysch $\mathrm{fm}$. & $40 \mathrm{~km} \mathrm{~N}$ of Fastelavnssø & 5 & & 31 & & & 31 \\
\hline Buen Fm. & Kedelkrogelv, Heinprin Ld. & 5 & 1 & 33 & & & 33 \\
\hline Portfjeld Fm. & Kedelkrogelv, Heinprin Ld. & 5 & 1 & 55 & & & 55 \\
\hline Portfjeld Fm. & Portfjeld, Wandel Dal & & 1 & 32 & 115 & & 147 \\
\hline Morænesø Fm., limestone & Morænesø & 3 & & & 29 & & 29 \\
\hline Morænesø Fm., 'tillite' & Morænesø & 4 & & 2 & 37 & & 39 \\
\hline Morænesø Fm., sandstone & Morænesø & 12 & & & 61 & & 61 \\
\hline Morænesø $\mathrm{Fm} .$, limestone & Wandel Dal & 9 & & & 35 & & 35 \\
\hline Morænesø Fm., 'tillite' & Wandel Dal & 10 & & & 35 & & 35 \\
\hline Midsommers $ø$ dolerites $^{\dagger}$ & Wandel Dal & 7 & & & 70 & & 70 \\
\hline Midsommersø (?) dykes ${ }^{\dagger}$ & $\mathrm{N}$ of Hagen Bræ & 2 & & 20 & & & 20 \\
\hline Zig-Zag Basalt Fm. $^{\dagger}$ & Zig-Zag Dal & 24 & & 76 & 122 & & 198 \\
\hline $\begin{array}{l}\text { Independence Fj. Gp./ } \\
\text { Fiil Fjord Mb. }\end{array}$ & Zig-Zag Dal & 1 & & 1 & 13 & & 14 \\
\hline \multicolumn{8}{|l|}{ Fiil Fjord Mb. } \\
\hline Siltstone unit & $\mathrm{N}$ of Hagen Bræ & 10 & & 19 & 65 & & 84 \\
\hline \multirow[t]{2}{*}{ Inuiteq Sø Fm. } & Wandel Dal & 14 & & & 35 & & 35 \\
\hline & & 116 & & 285 & 829 & 34 & 1114 \\
\hline
\end{tabular}

$\star$ Polystyrene beakers: ${ }^{\dagger}$ susceptibility measured in situ.

formably by the basal sandstone facies of the Campanuladal Formation (Clemmensen, 1979). As there is only scarce evidence of interbasaltic erosion it is suggested that the extrusion of the main part of the basalt lasted only for a short period, or a few short periods (Jepsen \& Kalsbeek, 1979).

\section{Sampling and laboratory work}

A total of 198, palaeomagnetic, sun compass orientated samples were collected from 24 sites in the basalt at Zig-Zag Dal (figs 60 \& 61, Table 13), to include at least 8 from each site, with the exception of the sites in the basal unit, where only 3 to 4 hand samples were collected in each case. Furthermore, the in situ magnetic susceptibility was measured at each site (20-30 individual readings per site) using a bridge type kappameter. In the laboratory several 1" orientated cores were drilled from each hand sample. From all cores specimens $2.3 \mathrm{~cm}$ long were cut to give a total of 882 specimens.

The NRM of all specimens was measured, using a Digico spinner magnetometer. Furthermore, the volume susceptibility of 538 of these selected specimens was measured. This compares with 536 in situ measurements. Another bridge type susceptibility meter was used for these laboratory measurements.

The directional statistical analysis of the NRM has been carried out at sample and site levels, using Fisherian statistics (Fisher, 1953), and the results summarized in Table 14. The mean value of the NRM intensity and susceptibility for each site is also given. 
Table 14. Zig-Zag Dal Basalt Formation, rock-magnetic results

\begin{tabular}{|c|c|c|c|c|c|c|c|c|c|}
\hline Site & $\begin{array}{c}\text { NRM } \\
10^{-4} \mathrm{emu} / \mathrm{cc}\end{array}$ & $\begin{array}{l}\text { Field susc. } \\
10^{-4} \mathrm{G} / \mathrm{Oe}\end{array}$ & $\begin{array}{l}\text { Lab.susc. } \\
10^{-4} \mathrm{G} / \mathrm{Oe}\end{array}$ & 0 & $N$ & $\mathrm{D}_{(0)}$ & $\mathrm{Im}_{(\mathrm{O})}$ & k & $\begin{array}{r}\alpha 95 \\
\left({ }^{\circ}\right)\end{array}$ \\
\hline $\begin{array}{l}\text { BA-06 } \\
\text { BA-07 }\end{array}$ & $\begin{array}{l}19.2 \\
10.3\end{array}$ & $\begin{array}{l}21.0 \\
32.0\end{array}$ & $\begin{array}{l}32.6 \\
32.3\end{array}$ & $\begin{array}{l}0.59 \\
0.32\end{array}$ & $\begin{array}{r}9 \\
10\end{array}$ & $\begin{array}{r}44.7 \\
303.4\end{array}$ & $\begin{array}{l}71.5 \\
66.6\end{array}$ & $\begin{array}{l}44.8 \\
43.5\end{array}$ & $\begin{array}{l}7.7 \\
7.4\end{array}$ \\
\hline $\begin{array}{l}\text { BA-01 } \\
\text { BA-02 }\end{array}$ & $\begin{array}{l}47.8 \\
50.2\end{array}$ & $\begin{array}{l}32.1 \\
31.1\end{array}$ & $\begin{array}{l}36.3 \\
33.4\end{array}$ & $\begin{array}{l}1.32 \\
1.50\end{array}$ & $\begin{array}{r}9 \\
10\end{array}$ & $\begin{array}{l}91.8 \\
90.8\end{array}$ & $\begin{array}{r}9.3 \\
13.1\end{array}$ & $\begin{array}{r}215.9 \\
23.1\end{array}$ & $\begin{array}{r}3.5 \\
10.2\end{array}$ \\
\hline $\begin{array}{l}\text { BA-03 } \\
\text { BA-04 } \\
\text { BA-05 } \\
\text { BA-08 } \\
\text { BA-09 } \\
\text { BA-10 }\end{array}$ & $\begin{array}{r}23.6 \\
14.4 \\
28.7 \\
6.7 \\
5.2 \\
16.3\end{array}$ & $\begin{array}{r}10.9 \\
14.2 \\
14.1 \\
16.2 \\
6.3 \\
45.8\end{array}$ & $\begin{array}{r}10.8 \\
14.5 \\
15.5 \\
17.4 \\
5.7 \\
50.6\end{array}$ & $\begin{array}{l}2.19 \\
0.99 \\
1.85 \\
0.39 \\
0.91 \\
0.32\end{array}$ & $\begin{array}{r}9 \\
8 \\
10 \\
9 \\
9 \\
9\end{array}$ & $\begin{array}{r}93.9 \\
90.7 \\
92.9 \\
87.0 \\
94.2 \\
101.8\end{array}$ & $\begin{array}{r}-12.3 \\
-12.0 \\
-12.1 \\
83.1 \\
27.8 \\
70.8\end{array}$ & $\begin{array}{r}191.0 \\
264.3 \\
202.6 \\
77.3 \\
268.1 \\
42.6\end{array}$ & $\begin{array}{l}3.7 \\
3.4 \\
3.4 \\
5.8 \\
3.1 \\
7.9\end{array}$ \\
\hline $\begin{array}{l}\text { BA-11 } \\
\text { BA-15 } \\
\text { BA-16 } \\
\text { BA-14 } \\
\text { BA-17 } \\
\text { BA-12 } \\
\text { BA-13 }\end{array}$ & $\begin{array}{r}30.2 \\
34.1 \\
21.8 \\
6.5 \\
9.2 \\
10.0 \\
8.3\end{array}$ & $\begin{array}{r}18.5 \\
18.8 \\
7.6 \\
24.5 \\
21.2 \\
26.2 \\
22.7\end{array}$ & $\begin{array}{r}17.3 \\
19.9 \\
7.0 \\
20.4 \\
21.1 \\
24.7 \\
22.7\end{array}$ & $\begin{array}{l}1.75 \\
1.71 \\
3.11 \\
0.32 \\
0.44 \\
0.41 \\
0.37\end{array}$ & $\begin{array}{r}9 \\
10 \\
10 \\
10 \\
9 \\
8 \\
9\end{array}$ & $\begin{array}{l}98.8 \\
99.3 \\
99.6 \\
74.7 \\
93.0 \\
87.0 \\
84.6\end{array}$ & $\begin{array}{r}-14.8 \\
-24.7 \\
-34.2 \\
58.1 \\
71.0 \\
73.3 \\
78.1\end{array}$ & $\begin{array}{r}865.6 \\
414.9 \\
154.7 \\
21.7 \\
20.9 \\
40.3 \\
478.1\end{array}$ & $\begin{array}{r}1.7 \\
2.3 \\
3.8 \\
10.5 \\
11.5 \\
8.8 \\
2.3\end{array}$ \\
\hline $\begin{array}{l}\text { BA-24 } \\
\text { BA-23 } \\
\text { BA-18 } \\
\text { BA-19 } \\
\text { BA-20 } \\
\text { BA-21 } \\
\text { BA-22 }\end{array}$ & $\begin{array}{r}119.5 \\
2.1 \\
0.8 \\
6.0 \\
7.7 \\
4.0 \\
12.8\end{array}$ & $\begin{array}{r}20.6 \\
9.5 \\
1.6 \\
9.3 \\
5.0 \\
6.5 \\
5.2\end{array}$ & $\begin{array}{r}21.2 \\
13.0 \\
2.0 \\
7.8 \\
9.7 \\
5.3 \\
12.1\end{array}$ & $\begin{array}{l}5.64 \\
0.16 \\
0.40 \\
0.77 \\
0.79 \\
0.76 \\
1.06\end{array}$ & $\begin{array}{r}10 \\
10 \\
3 \\
4 \\
3 \\
3 \\
3\end{array}$ & $\begin{array}{l}91.5 \\
10.8 \\
81.9 \\
76.9 \\
90.6 \\
91.7 \\
98.9\end{array}$ & $\begin{array}{r}-9.8 \\
62.6 \\
37.5 \\
60.2 \\
-4.9 \\
9.5 \\
-12.7\end{array}$ & $\begin{array}{r}200.4 \\
13.3 \\
77.6 \\
26.1 \\
2.6 \\
7.7 \\
84.2\end{array}$ & $\begin{array}{r}3.4 \\
13.7 \\
14.0 \\
18.2 \\
>90 \\
47.6 \\
13.5\end{array}$ \\
\hline $\begin{array}{l}\text { All sites } \\
\text { Confidence } \\
\text { interval } \\
\text { BA 3-5,8-10 } \\
\text { (sites in flow }\end{array}$ & $\begin{array}{c}12.3 \\
4.2-36.3\end{array}$ & $\begin{array}{c}13.9 \\
6.4-30.1\end{array}$ & $\begin{array}{c}15.2 \\
7.3-31.8\end{array}$ & 0.81 & 24 & 88.8 & 29.1 & 3.6 & 18.3 \\
\hline $\begin{array}{l}\text { no. 63) } \\
\text { Confidence } \\
\text { interval }\end{array}$ & $6.7-26.3$ & $\begin{array}{c}14.7 \\
7.7-28.2\end{array}$ & $\begin{array}{c}15.2 \\
7.4-31.0\end{array}$ & 0.86 & 6 & 93.3 & 22.6 & 3.6 & 41.1 \\
\hline
\end{tabular}

Sites in descending order, cf. fig. 61.

Note: The NRM, Field susc. and Lab. susc. figures tabulated are geometric mean values. The confidence intervals have been calculated using the formula: $\left[\log ^{-1}\left(\log \bar{x}-s\left(\log x_{j}\right)\right), \log ^{-1}\left(\log \dot{x}+\mathbf{s}\left(\log x_{i}\right)\right)\right]$.

$\mathrm{N}$ : number of samples and sites, respectively; $\mathrm{D}_{\mathrm{m}}$ and $\mathrm{I}_{\mathrm{m}}$ : mean declination and inclination of NRM;

Q: NRM/Lab.susc.; $k$ and $\alpha_{95}$ : precision parameter and radius of $95 \%$ confidence circle about the mean direction (Fisher, 1953).

\section{Rock-magnetic results}

In fig. 61 the mean values of NRM intensity, susceptibility and NRM direction (declination and inclination) are given in relation to the basalt sequence at Zig-Zag Dal. The intensity of the NRM varies by two orders of magnitude (BA-18: $1.0 \times 10^{-4} \mathrm{emu} / \mathrm{cc}$ to BA-24: $1.2 \times 10^{-2} \mathrm{emu} / \mathrm{cc}$ ). The lowest mean intensity is found in the apparently altered Basal unit, whereas the highest mean intensity is found in the very prominent flow no. 51 . The overall geometrical mean is $1.2 \times 10^{-3} \mathrm{emu} / \mathrm{cc}$ (confidence interval: 0.42 to $3.6 \times 10^{-3}$ $\mathrm{emu} / \mathrm{cc}$ ). This mean value does not take into account the apparently high intensity values of 


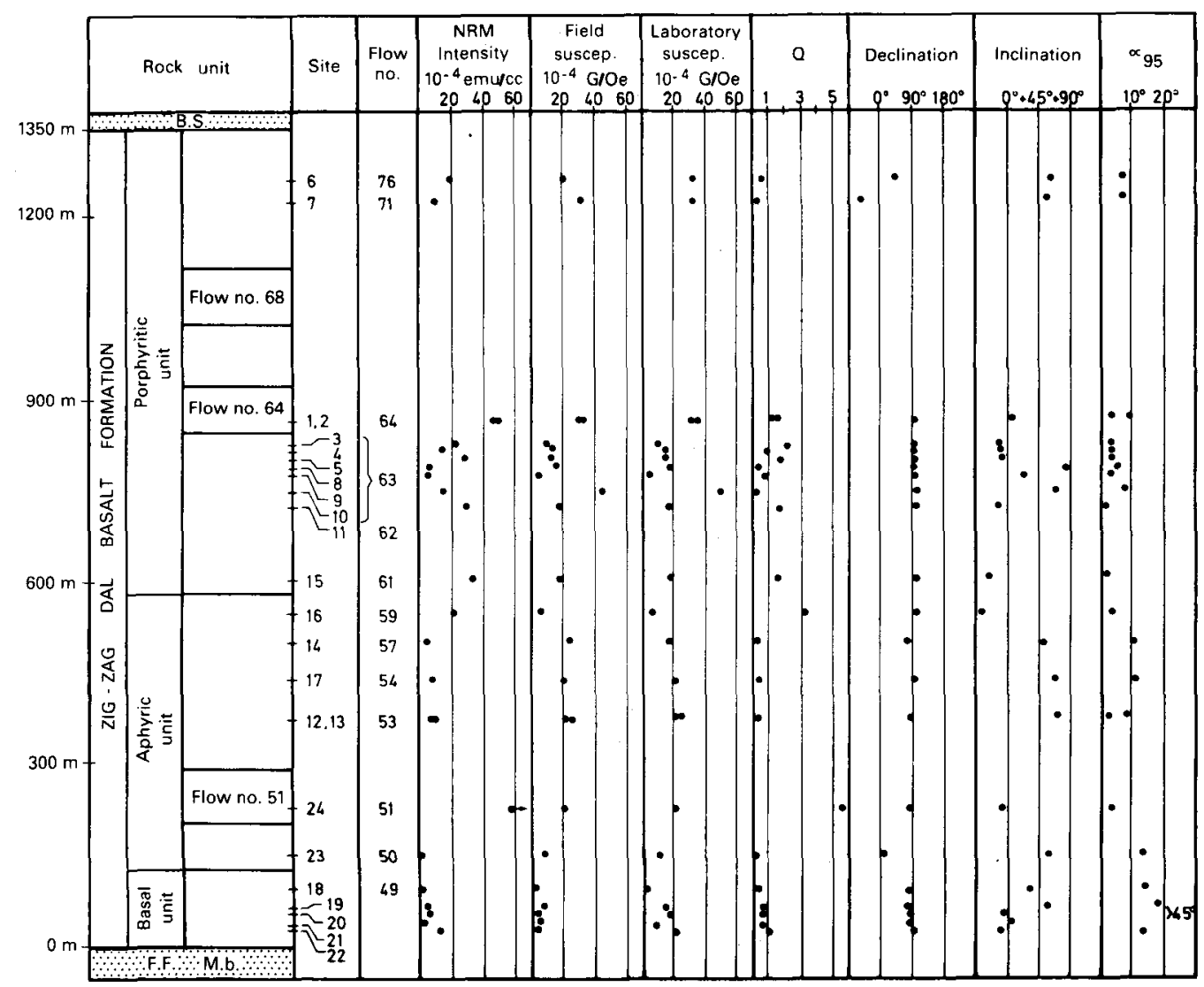

Fig. 61. Geological profile of the Proterozoic basalt series in Zig-Zag Dal in Mylius-Erichsen Land (Jepsen et al., this report) with rock- and palaeomagnetic mean data (cf. Table 14). FF Mb below the basalt is the Fiil Fjord Member of the Independence Fjord Group, whereas BS on top of the basalts is the basal sandstones of the Campanuladal Formation (Clemmensen, 1979).

the sampled prominent flows compared with those of the sampled minor flows. Therefore, a representative mean for the whole basalt sequence may well be slightly higher than the one given above and, for example, fall within the upper half of the given confidence interval.

The agreement between the two sets of susceptibility data is remarkably good, even though they were measured in different ways by two different instruments. The susceptibility varies between (a) $0.20 \times 10^{-3} \mathrm{G} / \mathrm{Oe}$ (site BA-18) and (b) $5.1 \times 10^{-3} \mathrm{G} / \mathrm{Oe}$ (site BA-10), with an overall mean of about (c) $1.5 \times 10^{-3} \mathrm{G} / \mathrm{Oe}$ (confidence interval: 0.73 to $3.3 \times 10^{-3}$ $\mathrm{G} / \mathrm{Oe}$ ), which is slightly higher than the average for oceanic basalts (Vacquier, 1972 Appendix 3). The corresponding $Q$ values $(Q=N R M / L a b . s u s c$.) vary between 0.3 and 5.6 with an overall mean of about 0.8 ; this is lower than the average for oceanic basalts.

The NRM spherical mean direction (Fisher, 1953) of the basalt is $D=89^{\circ}, I=29^{\circ}$ $\left(\alpha_{95}=18.3, N=24\right.$ sites), which is significantly different from the direction of the present 

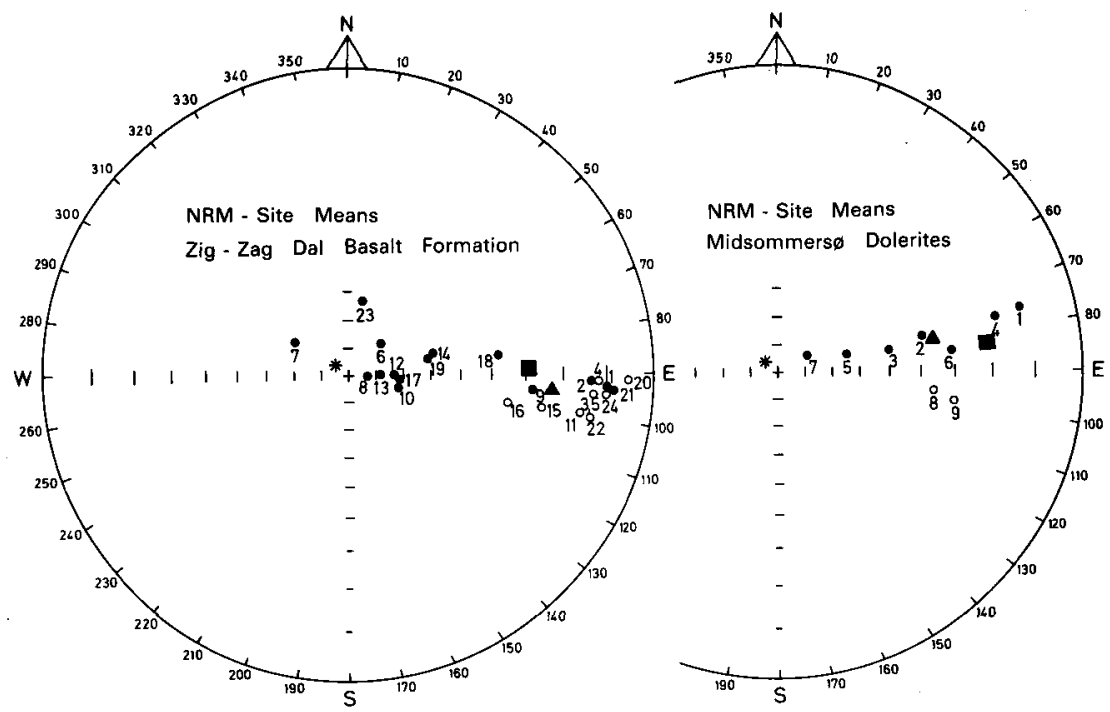

Fig. 62. Natural remnant magnetization (NRM) directions from the Zig-Zag Dal Basalt Formation (Table 14) and the Midsommersø Dolerites (Table 15) in stereographic projection. Solid and open symbols indicate positive and negative inclinations, respectively. Small dots and circles with site numbers are site mean directions, triangles are means of flow no. 63 and dolerite $01-06$, respectively, whereas squares are overall means.

The NRM directions appear to be scattered along two east-west, approximately vertical great circles, indicating that the resulting NRM is composed of at least two remanent components, a soft viscous component (in the present field direction) and a more stable, perhaps primary palaeomagnetic component.

geomagnetic field $\mathrm{D}_{0} \simeq 315^{\circ}, \mathrm{I}_{0} \simeq 82^{\circ}$ ). In fig. 62 , the site means of the NRM are plotted in stereographic projection. The inclination values are somewhat scattered, whereas the declination values generally trend towards the east. The mean directions appear to be scattered along a great circle; this may suggest that the direction of the primary magnetization is very different from the viscous components of the NRM induced by the present field. A full palaeomagnetic investigation including demagnetization is in progress and will be presented elsewhere.

\section{Midsommersø Dolerites}

The Proterozoic sandstones (the Independence Fjord Group, Collinson, this report) between western Peary Land and Mylius-Erichsen Land underlying the Zig-Zag Dal Basalt Formation contain numerous sills, sheets and dykes of dolerite, which make up the so-called Midsommersø dolerites (Jepsen, 1971; Jepsen \& Kalsbeek, 1979; Collinson, 1979). It has been suggested (Jepsen \& Kalsbeek, 1979) that the Zig-Zag Dal basaltic volcanism and the intrusion of the Midsommersø dolerites were contemporaneous and genetically related.

The dolerite samples representing three different localities were collected from nine sites. 
Table 15. Midsommersø dolerites, rock-magnetic results

\begin{tabular}{|c|c|c|c|c|c|c|c|c|c|}
\hline Site & $\begin{array}{c}\text { NRM } \\
10^{-4} \mathrm{emu} / \mathrm{cc}\end{array}$ & $\begin{array}{l}\text { Field susc. } \\
10^{-4} \mathrm{G} / \mathrm{Oe}\end{array}$ & $\begin{array}{l}\text { Lab.susc. } \\
10^{-4} \mathrm{G} / \mathrm{Oe}\end{array}$ & o & $N$ & $\mathrm{D}_{(0)}$ & $I^{\prime m}$ & $k$ & $\begin{array}{r}\alpha 95 \\
\left({ }^{\circ}\right)\end{array}$ \\
\hline DL-01 & 0.5 & 1.7 & 1.6 & 0.32 & 10 & 74.7 & 11.4 & 19.4 & 11.2 \\
\hline DL-02 & 9.6 & 22.8 & 25.3 & 0.38 & 13 & 75.7 & 37.9 & 27.2 & 8.0 \\
\hline DL-03 & 6.2 & 15.0 & 25.2 & 0.25 & 9 & 77.9 & 48.9 & 17.1 & 12.7 \\
\hline DL-04 & 15.2 & 28.2 & 28.7 & 0.54 & 10 & 75.6 & 17.3 & 82.1 & 5.3 \\
\hline DL-05 & 9.9 & 27.6 & 29.6 & 0.33 & 8 & 74.8 & 63.4 & 59.9 & 7.2 \\
\hline DL-06 & 13.0 & 29.4 & 31.2 & 0.42 & 9 & 82.5 & 30.3 & 83.4 & 5.6 \\
\hline DL-07 & 0.06 & - & 0.02 & 2.33 & 9 & 59.9 & 76.6 & 3.6 & 31.6 \\
\hline $\begin{array}{l}\text { DL-08 } \\
\text { DL-09 }\end{array}$ & $\begin{array}{l}81.8 \\
52.7\end{array}$ & $\begin{array}{l}44.2 \\
26.0\end{array}$ & $\begin{array}{l}43.7 \\
30.1\end{array}$ & $\begin{array}{l}1.87 \\
1.75\end{array}$ & $\begin{array}{l}10 \\
10\end{array}$ & $\begin{array}{l}96.3 \\
98.8\end{array}$ & $\begin{array}{l}-35.4 \\
-29.3\end{array}$ & $\begin{array}{r}95.4 \\
475.6\end{array}$ & $\begin{array}{l}4.9 \\
2.2\end{array}$ \\
\hline \multirow{2}{*}{$\begin{array}{l}\text { All sites } \\
\text { Confidence } \\
\text { interval }\end{array}$} & 11.2 & 18.6 & 20.8 & 0.54 & 8 & 82.3 & 19.2 & 5.2 & 26.7 \\
\hline & $2.4-52.1$ & $6.8-51.7$ & $7.3-59.6$ & & & & & & \\
\hline \multirow{2}{*}{$\begin{array}{l}\text { DL 1-6 } \\
\text { Confidence } \\
\text { interval }\end{array}$} & 6.2 & 15.4 & 17.3 & 0.36 & 6 & 76.0 & 34.8 & 17.2 & 16.6 \\
\hline & $1.7-22.2$ & $5.1-46.6$ & $5.4-55.8$ & & & & & & \\
\hline
\end{tabular}

Localities: DL-01-07 Wandel Dal

DL-08-09 North of Hagen Bræ.

Note: see note Table 14; DL-07 has been excluded from the overall mean for all sites, because this site was strongly weathered.

The first six sites (DL 01-06) were on a major sill (about $100 \mathrm{~m}$ thick) situated west of Øvre Midsommersø, DL-07 on a sill between Øvre and Nedre Midsommersø, and DL-08 and DL-09 on dykes on the north side of Hagen Bræ (fig. 60). A total of 90 palaeomagnetic samples were collected, with at least eight from each site. In the laboratory these samples were prepared, and a total of 342 specimens $2.3 \mathrm{~cm}$ long were obtained.

The Midsommersø dolerites were measured for NRM and susceptibility (235 selected specimens as compared to 246 field readings) and the results recorded in Table 15 . The dolerites have about the same NRM intensity values as the basalt, with an overall mean of $1.1 \times 10^{-3} \mathrm{emu} / \mathrm{cc}$ (confidence interval: $0.24 \times 10^{-3} \mathrm{emu} / \mathrm{cc}$ to $5.2 \times 10^{-3} \mathrm{emu} / \mathrm{cc}$ ).

The susceptibility of the dolerites varies between $0.16 \times 10^{-3} \mathrm{G} / \mathrm{Oe}$ (site DL-01) and 4.4 $\times 10^{-3} \mathrm{G} / \mathrm{Oe}$ (site DL-08) with an overall mean of $2.1 \times 10^{-3} \mathrm{G} / \mathrm{Oe}$ (confidence interval: 0.73 to $6.0 \times 10^{-3} \mathrm{G} / \mathrm{Oe}$ ). This value is about 40 per cent higher than the value for the basalt. The corresponding $Q$ value $(0.5)$ is therefore slightly lower than for the basalt.

The mean directions of the dolerites appear to be scattered along a great circle, as do those for the basalt (fig. 62). The direction of the mean NRM for the dolerites is $D=82^{\circ}$, $\mathrm{I}=19^{\circ}\left(\alpha_{95}=26.7^{\circ}, \mathrm{N}=8\right.$ sites $)$. This value is significantly different from the present geomagnetic field, but rather close to the value obtained for the basalt.

At this stage of the investigation it does not appear possible to distinguish between the basalt and the Midsommersø dolerites by means of their rock-magnetic properties.

\section{References}

Christie, R. L. \& Peel, J. S. 1977: Cambrian-Silurian stratigraphy of Børglum Elv, Peary Land, eastern North Greenland. Rapp. Grønlands geol. Unders. 82, 42 pp. 
Clemmensen, L. B. 1979: Notes on the palaeogeographical setting of the Eocambrian tillite-bearing sequence of southern Peary Land, North Greenland. Rapp. Grønlands geol. Unders. 88, 15-22.

Collinson, J. D. 1979: The Proterozoic sandstones between Heilprin Land and Mylius-Erichsen Land, eastern North Greenland. Rapp. Grønlands geol. Unders. 88, 5-10.

Dawes, P. R. 1973: The North Greenland fold belt: a clue to the history of the Arctic Ocean Basin and the Nares Strait Lineament. In Tarling, D. H. \& Runcorn, S. K. (edit.) Implications of continental drift to the earth sciences 2, 925-947. London: Academic Press.

Dawes, P. R. 1976: Precambrian to Tertiary of northern Greenland. In Escher, A. \& Watt, W. S. (edit.) Geology of Greenland, 149-303. Copenhagen: Geol. Surv. Greenland.

Dawes, P. R. \& Soper, N. J. 1973: Pre-Quaternary history of North Greenland. In Pitcher, M. G. (edit.) Arctic Geology. Mem. Amer. Ass. Petrol. Geol. 19, 117-134.

Fisher, R. 1953: Dispersion on a sphere. Proc. Roy. Soc. Lond. A 217, 295-305.

Hurst, J. M. \& Peel, J. S. 1979: Late Proterozoic (?) to Silurian stratigraphy of southern Wulff Land, North Greenland. Rapp. Grønlands geol. Unders. 91, 37-56.

Jepsen, H. 1971: The Precambrian, Eocambrian and early Palaeozoic stratigraphy of the Jørgen Brønlund Fjord area, Peary Land, North Greenland. Bull. Grønlands geol. Unders. 96 (also Meddr Grønland 192,2) 42 pp.

Jepsen, H. \& Kalsbeek, F. 1979: Igneous rocks in the Proterozoic platform of eastern North Greenland. Rapp. Grønlands geol. Unders. 88, 11-14.

Larsen, O., Dawes, P. R. \& Soper, N. J. 1978: Rb/Sr age of the Kap Washington Group, Peary Land, North Greenland, and its geotectonic implication. Rapp. Grønlands geol. Unders. 90, 115-119.

Vacquier, V. 1972: Geomagnetism in marine geology, 185 pp. Amsterdam: Elsevier.

Vogt, P. R., Feden, R. H., Eldholm, O. \& Sundvor, E. 1978: The ocean crust west and north of the Svalbard Archipelago: Synthesis and review of new results. Polarforschung 48, 1-19. 